\title{
Physics, Chemistry and Biology Teachers' Reasons for Choosing the Profession of Teaching and Their Levels of Job Satisfaction with Respect to Certain Variables
}

\author{
Medine Baran ${ }^{1}$, Abdulkadir Maskan ${ }^{1}$, Mukadder Baran ${ }^{2}$ \\ ${ }^{1}$ Dicle University, Department of Physics Education, Diyarbakır, Turkey \\ ${ }^{2}$ Hakkari University, Department of Science education, Hakkari, Turkey \\ Correspondence: Medine Baran, Dicle University, Department of Physics Education, Diyarbakır, Turkey
}

Received: February 25, 2015 Accepted: March 17, 2015 Online Published: March 28, 2015

doi:10.11114/jets.v3i3.691

URL: http://dx.doi.org/10.11114/jets.v3i3.691

\begin{abstract}
The purpose of this study was to determine teachers' reasons for choosing the profession of teaching and their level of job satisfaction and to investigate the effects of certain variables on their job satisfaction. The research data were collected via a questionnaire form to determine the demographic backgrounds of the participants and a Job Satisfaction Scale made up of 32 items in five parts. For the analysis of the data, descriptive statistics, t-test and Scheffe test were used. Of all the participants, $34.8 \%$ of them preferred to be a teacher just because they wanted to do the profession of teaching; $20.8 \%$ of them reported that they incidentally became a teacher; $16.8 \%$ of them stated they became a teacher as it was easy to get employed after graduation; and only $0.7 \%$ of them believed the salary was satisfactory. The mean score of the participating teachers' overall responses to the scale was calculated as 66.5 , which demonstrated that the teachers had a moderate level of satisfaction with their jobs. Moreover, it was seen that the teachers' levels of job satisfaction differed significantly with respect to their gender, age and fields of teaching.
\end{abstract}

Keywords: physics-chemistry-biology teachers, choosing profession, job satisfaction levels, teachers' problems

\section{Introduction}

Job satisfaction, a bipolar concept defining the satisfaction or dissatisfaction of workers with their jobs, is still a matter of interest and intensive research today as it was in 1900s (Günbayı \& Toprak, 2010; Ertürk \& Keçecioğlu, 2012). Newstrom (1986) defines job satisfaction as workers' positive or negative feelings and emotions regarding their jobs. Job satisfaction refers to total attitudes of workers towards their jobs. These attitudes are apparent in the evaluation of jobs and the organization of employment. Brayfield and Rothe (1951) define job satisfaction as individuals' attitudes (feelings) regarding their jobs. Hoppock refers to job satisfaction as a different combination of psychological, physiological and environmental conditions that make a person say "I am fairly satisfied with my job". Therefore, for individuals in organizations as well as for these organizations, the concept of job satisfaction is now defined extensively (Rinehart \& Short, 2003). According to Davis (1988), job satisfaction is the satisfaction or dissatisfaction of workers with their jobs. Job satisfaction occurs when the features of a job fit workers' demands. Vroom regards job satisfaction as a part of various job attitudes of workers regarding their perceptions, emotions and behavior (Şimşek, 1995). According to Akçamete (2001), job satisfaction means meeting the values regarding a worker's job in the workplace. As can be seen in these definitions, job satisfaction, in its simple meaning, demonstrates how happy the worker is with his or her job. Workers' motivation has a close relationship with job satisfaction. In organizational sense, maintaining motivation is defined as the process of behaving in a way to lead to satisfaction to meet various needs of workers (Silah, 2005). In this process, the needs of workers constantly change, while differences occur in their behavior. Thus, it could be stated that workers levels of job satisfaction decrease or increase depending on their motivation levels. In literature, motivation theories generally fall into two categories: content theories and process theories (Efil, 2006). According to content theories, it is necessary to recognize the factors that cause individuals to behave as they like. Therefore, the initial motivation theories tried to find answers to the question of "what motivates people?" Maslow's (1954) Hierarchy of Needs, Herzberg's (1959) Theory of Double Factors, Alderfer's (1972) ERG Theory (Existence, Relatedness and Growth Theory) and McClelland's (1961) Theory of Motives for Success could be considered to be examples of content theories (Cited in Lunenburg \& Ornstein, 2000; Bassett-Jones \& Lloyd, 2005). 
Hierarchy of Needs is one of the most well-known theories developed by Maslow (1970). According to this theory, all behaviors of an individual are for meeting his or her own certain needs. In addition, the individual has needs that should be met in a certain order. Without meeting the lower levels of needs, the individual cannot demonstrate any behavior regarding his or her upper levels of needs. According to Maslow, an individual's needs include biological and physiological needs, safety needs, belongingness and love needs, self-expression need and self-actualization needs. Thus, if managers can be aware of which needs of their workers they want to meet, they can then direct their workers' behavior by creating the environment to help meet those needs. What is important for managers is to understand individuals' needs and to behave accordingly. According to another content theory developed in relation to motivation, Herzberg' theory, some factors have a relationship with satisfaction in the workplace and some with dissatisfaction. Herzberg examined these factors in two parts: external motivators and internal motivators. Internal factors were regarded as motivators developed based on a person's responsibilities, the job itself and on his or her achievements (Judge et al. 2001). Examples of external factors, also defined by Herzberg as hygiene factors, include institutional policies directly related to dissatisfaction, bad conditions at work, insufficient wage and safety problems (Northcraft \& Neale, 1990:139). Good external factors lead to motivation, yet dissatisfaction with external factors has preventive effects on motivation. When there are encouraging (internal) factors, high level of motivation occurs. In order to maintain job satisfaction, institutions should make the job more interesting and focus on such motivation factors as personal awards (Judge et al. 2001). In McClelland's theory, the focus is on three needs regarding the working environment. These are achievement, relationships and power. McClelland states that depending on workers' current carrier steps, some of these requirements are more prominent (Efil, 2006).

In later studies, it was pointed out that the question of "What motivates people?" is not efficient to explain the motivation and that what is more important is the question of "How do people get motivated?" This point of view has resulted in process theories regarding motivation. Process theories are motivation theories trying to explain how people get motivated. These process theories include Vroom's (1964) Expectation Theory, Adams's (1965) Equality Theory and Locke's (1968) Theory of Setting Goals (Cited in Lunenburg \& Ornstein, 2000; Bassett-Jones \& Lloyd, 2005). According to Vroom's (1964) Expectation Theory, people try to reach the results they find appealing and achievable. Whether something is appealing or not depends on whether it eventually provides benefits for the person or not (Yücel and Gülveren, 2008). Process theories deal with how the motivation process functions and how and for what purposes individuals get motivated. Rollinson and Broadfield (2002) point out that process theories focus not only on events influential on the power of motivation but also on mental processes that transform a motivation into a certain pattern of behavior. As mentioned in theories related to workers' levels of job satisfaction, job satisfaction is influenced by a number of variables as well as has influence on many variables.

Today, not only determining teachers' levels of job satisfaction and the factors influential on their job satisfaction but also taking related measures is very important for the sake of education given to students. In Turkey, just as it is in the world, the factors leading to teachers' dissatisfaction with their jobs cause teachers not only to feel dissatisfaction with their jobs but also to give up their current job to find a new one (Delfgaauw, 2005). Darling Hammond (2001) pointed out that almost $30 \%$ of newly-appointed teachers give up teaching in their first five years of teaching and that especially special education teachers have a higher tendency to give up teaching than teachers in other fields (Williams and Poel, 2006, p.3). George, Gersten and Grosenick (1995) stated that more than $36 \%$ of teachers plan to give up teaching in a period of one year. In one study titled 'Alienation in Education and the Teacher', Erjem (2005) refers to "job dissatisfaction" as an indicator of alienation. According to the findings obtained via the interviews held with the teachers, $65 \%$ of them emphasized that they were not satisfied with their jobs. The teachers attributed their dissatisfaction to such causes especially as the school conditions, crowded classrooms, students who are not prepared for classes and the workload of classes. In national and international studies carried out with teachers, there is no consensus on what leads to dissatisfaction. In addition, several factors such as gender, working conditions, the job difficulty, financial conditions, experience in teaching, relationships with colleagues, institutional functions and policies, promotional opportunities within the institution, administration and inspection are some of the most important factors influencing teachers' levels of job satisfaction. However, how and to what extent these factors influence teachers' job satisfaction has always been a matter of debate and research.

The purpose of the present study was not only to determine the most important reasons why the participating physics, chemistry and biology teachers preferred to become a teacher but also to reveal what the job satisfaction levels of the teachers as well as whether their job satisfaction levels differed significantly with respect to certain variables. In line with the findings obtained, various suggestions were put forward to increase teachers' levels of job satisfaction. 


\section{Method}

\subsection{Participants}

The participants of the present study were 278 physics, chemistry and biology teachers, 225 of whom (81\%) were teaching in the secondary schools in the central town of Diyarbakır (Turkey) and 53 of whom (19\%) were teaching in the secondary schools in the academic year of 2011-2012. Of all the participants, 96 of them were physics teachers $(34.5 \%) ; 97$ of them (34.9\%) were chemistry teachers; and 85 of them (30,6\%) were biology teachers. In addition, 100 of the teachers were female (36\%), and 178 of them were male $(64 \%)$. Of all the participating teachers, 206 of them (74.1\%) had an experience of 1-5 years in teaching; 36 of them $(12,9 \%)$ had an experience of 6-10 years; 16 of them $(5,8 \%)$ had an experience of 16-20 years; and 21 of them $(1,4 \%)$ had 21 or longer years of teaching experience. Among all the participants, 4 of them $(1,4 \%)$ had a monthly income of 685 TLs; 20 of them $(7,2 \%)$ had a monthly income of $685-1000$ TLs; 15 of them (5,4\%) had a monthly income of 1000-1500 TLs; 189 of them (68\%) had a monthly income of $1500-2000 \mathrm{TLs} ; 43$ of them (15,5\%) had a monthly income of 2000-2500 TLs; and 7 of them (2,5\%) had a monthly income of 2500 TLs or higher.

\subsection{Data Collection Tools}

In order to collect the research data from the participating teachers, a questionnaire made up of two parts was used. The first part of the questionnaire included 10 items regarding the demographic backgrounds of the participants. As for the second part, it was made up of Job Description Index (JDI) items. Job Description Index was first developed in 1959 by Patricia Can Smith and colleagues for the purpose of "helping future researchers with their studies" (Smith et.al., 1969). The Turkish version of JDI was used by Becerikli (2003). The JDI questionnaire is a standard scale made up of two parts measuring the job satisfaction levels of workers. As the original form of JDI was in a constant development process until 2009, it is regarded one of the most original job satisfaction scales. The first part of JDI includes 10 items examining the reasons why workers have chosen their jobs, and the second part is made up of 32 3-option items. For each item, there were such options as "I agree", "I am neutral" and "I disagree" to reveal the participating teachers' views about the statements. The positive items found in the scale were scored as 3,2 or 1, and the negative ones were reversely-scored as 1,2 or 3 . The teachers' overall responses to the statements in the scale produced the maximum score of 96 and the minimum score of 32 .

Table 1. Distribution of the minimum and maximum scores obtained from the job satisfaction scale

\begin{tabular}{lrrllc}
\hline \multicolumn{1}{c}{ Sub-dimension } & $\mathrm{N}$ & Min. & Max. & Mean & Standard Deviation \\
\hline Job-related features & 278 & 14 & 36 & 26.18 & 4.330 \\
Your salary & 278 & 4 & 12 & 6.15 & 1.814 \\
Promotion & & & & & \\
Opportunities & 278 & 4 & 12 & 5.99 & 1.915 \\
Your administrators & 278 & 6 & 18 & 14.09 & 3.466 \\
Your Colleagues & 278 & 6 & 18 & 14.10 & 3.089 \\
Total & 278 & 41 & 89 & 66.51 & 9.571 \\
\hline
\end{tabular}

The validity of the scale was calculated, and the Cronbach Alpha coefficient for the total scale was found to be 0.811 . For the validity of the scale, the scale items were evaluated together with experts in the fields of measurement/assessment, field teaching and Turkish Language depending on the face-to-face interviews held with the participating teachers. These evaluations focused on whether the items in the scale were comprehensive and easy to understand; whether the items measured the teachers' levels of job satisfaction and their reasons for choosing their jobs; as well as on whether their levels of job satisfaction differed with respect to certain variables. In line with the suggestions put forward as a result of these interviews, the necessary corrections were, if any, made on the scale items by the researchers.

The second part of the scale included five sub-dimensions: job-related features, salary, promotion opportunities, administrators and colleagues.

\subsection{Data Analysis}

In order to analyze the data collected regarding the demographic backgrounds of the participants and the data collected via the first part of the Job Description Index, frequencies, percentages and mean scores were used. For the analysis of the 32-item part of the scale, standard deviations and t-tests were applied. As for the multiple comparisons, Scheffe test was used. For the analyses, the SPSS version 15.0 package software program was used.

\section{Findings}

This section first presents the most important reasons why the physics, chemistry and biology teachers preferred the 
profession of teaching. Following this, the findings regarding their levels of job satisfaction as well as regarding whether their levels of job satisfaction differed significantly with respect to their gender, school type, experience in teaching and the location of their schools are presented. Table 2 demonstrates the results of the frequency analysis regarding the reasons why the teachers preferred the profession of teaching.

Table 2. Results of the frequency analysis regarding the study group teachers' reasons for choosing the profession of teaching

\begin{tabular}{lll}
\hline Items & $\mathrm{f}$ & $\%$ \\
\hline 1. It allows me to do the job I want & 97 & 34.8 \\
2. It provides the chance to take responsibility & 15 & 5.4 \\
3. It allows progress in business life & 3 & 1.1 \\
4. The workplace is suitable for me & 16 & 5.7 \\
5. This job is appropriate to the demands of my family & 14 & 5.0 \\
6. I have chosen this job based on others' recommendations & 6 & 2.2 \\
7. Finding a job is guaranteed & 47 & 16.8 \\
8. The salary is satisfactory & 2 & 0.7 \\
9. I became a teacher completely by chance & 58 & 20.8 \\
10. Other (Obligation, wrong choice, university placement test, fate and so on) & 20 & 7.2 \\
Total & 278 & 100 \\
\hline
\end{tabular}

The results presented in Table 2 demonstrated that $34,8 \%$ of the participating teachers wanted to become a teacher; that $20.8 \%$ of them became a teacher completely by chance; that $16.8 \%$ of them thought finding a job was guaranteed; that only $0.7 \%$ of them found the salary satisfying.

Table 3. Difference between job satisfaction scores with respect to gender

\begin{tabular}{lllllcc}
\hline \multicolumn{1}{c}{ Items } & & $\mathrm{N}$ & Mean & Standard Deviation & $\mathrm{t}$ & $\mathrm{p}$ \\
\hline Job & 1 & 100 & 27.16 & 3.697 & 2.866 & $0.004^{*}$ \\
& 2 & 178 & 25.63 & 4.566 & & \\
Salary & 1 & 100 & 6.28 & 1.939 & .888 & 0.375 \\
& 2 & 178 & 6.08 & 1.742 & & \\
Promotion & 1 & 100 & 6.36 & 2.077 & 2.465 & $0.014^{*}$ \\
& 2 & 178 & 5.78 & 1.790 & & \\
Administrator & 1 & 100 & 14.27 & 3.357 & 0.636 & 0.526 \\
& 2 & 178 & 13.99 & 3.531 & & \\
Colleague & 1 & 100 & 14.21 & 2.844 & & \\
& 2 & 178 & 14.03 & 3.224 & 0.456 & 0.649 \\
General & 1 & 100 & 68.28 & 8.347 & & \\
Satisfaction & 2 & 178 & 65.51 & 10.081 & 2.333 & \\
& & & & & & $0.020^{*}$ \\
\hline
\end{tabular}

1: Female, 2: Male

When Table 3 was examined, it was seen that with respect to gender, there were significant differences between the job satisfaction scores of the female and male teachers in terms of doing their profession, promotion opportunities and general satisfaction in favor of the female participants. 
Table 4. Difference between job satisfaction scores with respect to school type

\begin{tabular}{|c|c|c|c|c|c|c|c|}
\hline Items & & Sum of Squares & $\mathrm{df}$ & Mean square & & $\mathrm{F}$ & $\mathrm{P}$ \\
\hline \multirow[t]{3}{*}{ Job } & Between groups & 115.460 & 7 & 16.494 & .877 & & .525 \\
\hline & Within group & 5077.547 & 270 & 18.806 & & & \\
\hline & Total & 5193.007 & 277 & & & & \\
\hline \multirow{3}{*}{ Salary } & Between groups & 37.159 & 7 & 5.308 & 1.639 & & .124 \\
\hline & Within group & 874.495 & 270 & 3.239 & & & \\
\hline & Total & 911.655 & 277 & & & & \\
\hline \multirow[t]{3}{*}{ Promotion } & Between groups & 25.758 & 7 & 3.680 & 1.003 & & .429 \\
\hline & Within group & 990.185 & 270 & 3.667 & & & \\
\hline & Total & 1015.942 & 277 & & & & \\
\hline \multirow[t]{3}{*}{ Administrators } & Between groups & 41.917 & 7 & 5.988 & .492 & & .840 \\
\hline & Within group & 3285.651 & 270 & 12.169 & & & \\
\hline & Total & 3327.568 & 277 & & & & \\
\hline \multirow[t]{3}{*}{ Colleagues } & Between groups & 21.078 & 7 & 3.011 & .310 & & .949 \\
\hline & Within group & 2621.300 & 270 & 9.709 & & & \\
\hline & Total & 2642.378 & 277 & & & & \\
\hline General & Between groups & 317.383 & 7 & 45.340 & .489 & & .843 \\
\hline \multirow[t]{2}{*}{ Satisfaction } & Within group & 25058.103 & 270 & 92.808 & & & \\
\hline & Total & 25375.486 & 277 & & & & \\
\hline
\end{tabular}

As can be seen in Table 4, no significant difference was found between the job satisfaction scores of the study group with respect to their school type

Table 5. Difference between job satisfaction scores with respect to experience in teaching

\begin{tabular}{|c|c|c|c|c|c|c|}
\hline Items & & Sum of Squares & Df & Mean square & $\mathrm{F}$ & $\mathrm{P}$ \\
\hline \multirow[t]{3}{*}{ Job } & Between groups & 107.842 & 4 & 26.960 & 1.447 & .219 \\
\hline & Within group & 5085.166 & 273 & 18.627 & & \\
\hline & Total & 5193.007 & 277 & & & \\
\hline \multirow[t]{3}{*}{ Salary } & Between groups & 22.584 & 4 & & & \\
\hline & Within group & 889.071 & 273 & 5.646 & 1.734 & .143 \\
\hline & Total & 911.655 & 277 & & & \\
\hline Promotion & Between groups & 33.219 & 4 & 8.305 & 2.307 & .058 \\
\hline \multirow[t]{2}{*}{ opportunitie } & Within group & 982.723 & 273 & 3.600 & & \\
\hline & Total & 1015.942 & 277 & & & \\
\hline \multirow[t]{3}{*}{ Colleagues } & Between groups & 7.650 & 4 & 1.912 & .198 & .939 \\
\hline & Within group & 2634.728 & 273 & 9.651 & & \\
\hline & Total & 2642.378 & 277 & & & \\
\hline General & Between groups & 620.818 & 4 & 155.204 & 1.712 & .148 \\
\hline \multirow[t]{2}{*}{ Satisfaction } & Within group & 24754.668 & 273 & 90.676 & & \\
\hline & Total & 25375.486 & 277 & & & \\
\hline \multirow[t]{3}{*}{ Administrators } & Between groups & 75.597 & 4 & & & \\
\hline & Within group & 3251.971 & 273 & 18.899 & 1.587 & .178 \\
\hline & Total & 3327.568 & 277 & 11.912 & & \\
\hline
\end{tabular}

The results presented in Table 5 did not reveal any significant difference between the job satisfaction scores of the study group with respect to their experience in teaching.

Table 6. Difference between job satisfaction scores with respect to age

\begin{tabular}{|c|c|c|c|c|c|c|c|}
\hline & & Sum of Squares & Df & Mean Square & $\mathrm{F}$ & $\mathrm{P}$ & Sheffe \\
\hline \multirow[t]{4}{*}{ Job } & Between groups & 73.212 & 3 & 24.404 & 1.306 & .273 & \\
\hline & Within group & 5119.795 & 274 & 18.685 & & & \\
\hline & Total & 5193.007 & 277 & & & & \\
\hline & Between groups & 11.994 & & & & & \\
\hline \multirow[t]{2}{*}{ Salary } & Within group & 899.661 & 3 & 3.998 & 1.218 & & \\
\hline & Total & 911.655 & $\begin{array}{l}274 \\
277\end{array}$ & 3.283 & & .304 & \\
\hline \multirow{3}{*}{ Promotion opportunities } & Between groups & 29.769 & 3 & 9.923 & 2.757 & & $1-3$ \\
\hline & Within group & 986.173 & 274 & 3.599 & & $.043 *$ & \\
\hline & Total & 1015.942 & 277 & & & & \\
\hline \multirow[t]{3}{*}{ Administrators } & Between groups & 18.205 & 3 & & & & \\
\hline & Within group & 3309.364 & 274 & 6.068 & & .681 & \\
\hline & Total & 3327.568 & 277 & 12.078 & .502 & & \\
\hline \multirow[t]{3}{*}{ Colleagues } & Between groups & 20.328 & 3 & & & & \\
\hline & Within group & 2622.049 & 274 & & & .548 & \\
\hline & Total & 2642.378 & 277 & $\begin{array}{l}6.776 \\
9.570\end{array}$ & .708 & & \\
\hline \multirow[t]{3}{*}{ General satisfaction } & Between groups & 572.250 & 3 & 190.750 & & .100 & \\
\hline & Within group & 24803.235 & 274 & 90.523 & 2.107 & & \\
\hline & Total & 25375.486 & 277 & & & & \\
\hline
\end{tabular}

1= 20-30 Age group, 2=31-40 Age group, 3=41-50 Age group, 4=51 and higher Age group

When Table 6 is examined, it is seen that with respect to the promotion opportunities, there were significant differences 
between the teachers aged 20 to 30 and those aged 41 to 50 in favor of the former group of teachers. It was found out that the teachers aged 20 to 30 were more satisfied in terms of the promotion opportunities when compared to the teachers aged 41 to $50(\mathrm{X} 1-\mathrm{X} 3=.962)$.

Table 7. Difference between job satisfaction scores with respect to school location

\begin{tabular}{|c|c|c|c|c|c|c|}
\hline $\mathrm{N}$ & & Mean & Standard Deviation & & $\mathrm{t}$ & $\mathrm{p}$ \\
\hline \multirow[t]{2}{*}{ Job } & 1 & 225 & 26.28 & 4.359 & .794 & .428 \\
\hline & 2 & 53 & 25.75 & 4.219 & & \\
\hline \multirow[t]{2}{*}{ Salary } & 1 & 225 & 6.07 & 1.764 & -1.518 & .130 \\
\hline & 2 & 53 & 6.49 & 1.996 & & \\
\hline \multirow[t]{2}{*}{ Promotion opportunities } & 1 & 225 & 5.96 & 1.943 & -.379 & .705 \\
\hline & 2 & 53 & 6.08 & 1.806 & & \\
\hline \multirow[t]{2}{*}{ Administrators } & 1 & 225 & 14.04 & 3.444 & .486 & .627 \\
\hline & 2 & 53 & 14.30 & 3.582 & & \\
\hline \multirow[t]{2}{*}{ Colleagues } & & & & & & \\
\hline & 2 & 225 & 14.02 & 3.161 & -.882 & .378 \\
\hline \multirow[t]{4}{*}{ General satisfaction } & 1 & 53 & 14.43 & 2.763 & & \\
\hline & 2 & & & & & \\
\hline & & 225 & 66.38 & 9.547 & -.464 & .643 \\
\hline & & 53 & 67.06 & 9.748 & & \\
\hline
\end{tabular}

\section{1: City center, 2: District}

When Table 7 is examined, it is seen that the study group teachers' job satisfaction scores did not differ with respect to the location of their schools.

Table 8. Difference between job satisfaction scores with respect to field of teaching

\begin{tabular}{|c|c|c|c|c|c|c|}
\hline Items & & Sum of Squares & Df & Mean square & $\mathrm{F}$ & $\mathrm{P}$ \\
\hline \multirow[t]{3}{*}{ Job } & Between groups & 20.904 & 2 & 10.452 & .556 & .574 \\
\hline & Within groups & 5172.103 & 275 & 18.808 & & \\
\hline & Total & 5193.007 & 277 & & & \\
\hline \multirow[t]{3}{*}{ Salary } & Between groups & 5.076 & 2 & 2.538 & .770 & .464 \\
\hline & Within groups & 906.579 & 275 & 3.297 & & \\
\hline & Total & 911.655 & 277 & & & \\
\hline Promotion & Between groups & & & & & \\
\hline \multirow[t]{3}{*}{ Opportunities } & Within groups & 14.605 & 2 & & & \\
\hline & Total & 1001.337 & 275 & 7.303 & 2.006 & .137 \\
\hline & & 1015.942 & 277 & 3.641 & & \\
\hline \multirow[t]{3}{*}{ Administrators } & Between groups & 17.703 & 2 & 8.851 & .735 & .480 \\
\hline & Within groups & 3309.866 & 275 & 12.036 & & \\
\hline & Total & 3327.568 & 277 & & & \\
\hline \multirow[t]{3}{*}{ Colleagues } & Between groups & 66.488 & 2 & 33.244 & 3.549 & $.030 *(3-2)$ \\
\hline & Within groups & 2575.890 & 275 & 9.367 & & \\
\hline & Total & 2642.378 & 277 & & & \\
\hline General & Between groups & & & & & \\
\hline \multirow[t]{3}{*}{ Satisfaction } & Within groups & 307.394 & 2 & 153.697 & 1.686 & \\
\hline & Total & 25068.092 & 275 & 91.157 & & .187 \\
\hline & & 25375.486 & 277 & & & \\
\hline
\end{tabular}

\section{2: Biology teachers, 3: Chemistry teachers}

As can be seen in Table 8, when the job satisfaction scores of the study group teachers were examined with respect to their fields of teaching, it was found out that the chemistry teachers were more satisfied in terms of their colleagues than the biology teachers $(\mathrm{X} 3-\mathrm{X} 2=1,198)$.

Table 9. Distribution of the job satisfaction scores with respect to marital status

\begin{tabular}{lllllll}
\hline & Marital Status & $\mathrm{N}$ & Mean & Std. Deviation & $\mathrm{T}$ & $\mathrm{p}$ \\
\hline Job & 1 & 203 & 26.03 & 4.263 & -.921 & .358 \\
Salary & 2 & 75 & 26.57 & 4.512 & & \\
& 1 & 203 & 6.14 & 1.816 & -.198 & .843 \\
Promotional opportunities & 1 & 75 & 6.19 & 1.821 & & \\
& 2 & 203 & 5.84 & 1.773 & -2.064 & $.040^{*}$ \\
Administrators & 2 & 75 & 6.37 & 2.223 & & \\
Colleagues & 1 & 203 & 13.98 & 3.468 & -.896 & .371 \\
& 2 & 75 & 14.40 & 3.464 & & \\
General Satisfaction & 1 & 203 & 14.31 & 3.086 & & .058 \\
& 2 & 75 & 13.52 & 3.042 & 1.903 & \\
& 1 & 203 & 66.31 & 9.491 & -.578 & .564 \\
\hline
\end{tabular}




\section{1: Married, 2: Single}

When Table 9 is examined, it is seen that the participating teachers who were single believed they had better promotion opportunities than the teachers who were married $(\mathrm{p}<.05)$.

Table 10. Distribution of job satisfaction scores with respect to field of graduation

\begin{tabular}{lllllll}
\hline Items & Field of graduation & $\mathrm{N}$ & Mean & Std. Deviation & $\mathrm{t}$ & $\mathrm{p}$ \\
\hline Job & 2 & 223 & 26.05 & 4.186 & -.977 & .329 \\
& 3 & 55 & 26.69 & 4.880 & & \\
Salary & 2 & 223 & 6.09 & 1.800 & -1.053 & .293 \\
& 3 & 55 & 6.38 & 1.871 & & \\
Promotion opportunities & 2 & 223 & 5.85 & 1.783 & -2.361 & .019 \\
Administrators & 3 & 55 & 6.53 & 2.316 & & \\
& 2 & 223 & 14.12 & 3.469 & .223 & .824 \\
Colleagues & 3 & 55 & 14.00 & 3.485 & & \\
\multirow{3}{*}{ General Satisfaction } & 2 & 223 & 14.07 & 3.105 & -.275 & .783 \\
& 3 & 55 & 14.20 & 3.045 & & \\
& 2 & 223 & 66.19 & 9.180 & & .264 \\
\hline
\end{tabular}

2: Undergraduate degree 3: Post-graduate degree

When Table 10 is examined, it is seen that the participating science teachers who had a post-graduate degree believed they had better promotion opportunities when compared to the science teachers who had a Bachelor's $(\mathrm{p}<.05)$.

\section{Results and Discussion}

The present study was carried out with 278 physics, chemistry and biology teachers from Turkey, not only to determine their job satisfaction levels as well as the reasons why they preferred the profession of teaching but also to examine whether their job satisfaction levels differed with respect to certain variables. The mean score regarding the participating teachers' overall responses to the statements in the Job Description Index was calculated as 66.5 (maximum score $=96$; minimum score $=32$ ). This mean score demonstrates that the participating teachers had a moderate level of job satisfaction. On the other hand, workers' job satisfaction level is quite important for the success of the institution. Workers' higher levels of job satisfaction increase their motivation, cause them to do their job more willingly and thus increase the quality of the job they do (Bateman \& Organ, 1983; Nidich \& Nidich, 1986; Firestone \& Rosenblum, 1988; Koç, Yazıcıoğlu and Hatipoğlu, 2009). Teachers with low levels of job satisfaction are likely to cause trouble at school, constantly complain about everything and demonstrate such behavior as gossiping, resistance to renovations and discord with colleagues (Davis, 1982; Balc1, 1985; Mitchell \& Larson, 1987; Başaran, 2000; Eren, 2000).

As can be seen in Table 2, 34,8\% of the teachers stated that they became a teacher as they wanted to; $20,8 \%$ of them became a teacher completely by chance; $16,8 \%$ of them thought finding a job was guaranteed; $5 \%$ of them believed the profession of teaching met their family demands; and only $0,7 \%$ of them found the salary satisfying. In addition, of all the teachers, $21.9 \%$ of them pointed out that they preferred this profession due to various external factors. It is possible to find similar results in other related studies reported in literature. All these findings, as reported by previous studies, are consistent with the fact that professional preferences are influenced by financial (Behymer \& Cockriel, 2005; Kniveton, 2004) or external factors (Bastick, 2000; Boz \& Boz, 2008; Papanastasiou \& Papanastasiou, 1998; Saban, 2003). In addition, the findings obtained in the present study also shed light on why the rate of those who give up the profession of teaching is high (Erden, 2008). In short, it could be stated that those basing their job preferences on their own benefits and on external factors regard the job as a "safety valve" and that they easily give up their job when they find another job with better opportunities. In a study conducted in Turkey by the Turkish Education Association (2009) on "Teachers' Competencies" with 2007 teachers (973 elementary school teachers and 1034 teachers from other branches), it was revealed that $28.4 \%$ of the branch teachers became a teacher as it was their ideal job; that $21,4 \%$ of them became a teacher as finding a job was almost guaranteed; that $13,8 \%$ of them wanted to be beneficial for the society and children; and that $7,7 \%$ of them became a teacher in line with their families' demands. It was seen that with respect to their gender, there were significant differences between the female and male study group teachers' job satisfaction scores in terms of doing their profession, promotion opportunities and general satisfaction in favor of the female participants. In a study carried out by Ololube (2006) with 680 teachers from 146 public secondary schools in Nigeria Rivers State, it was found out that the female teachers had higher levels of job satisfaction than their male peers. Another similar study carried out on teachers' job satisfaction levels was conducted with 785 randomly-selected teachers from public high schools in Pakistan. In this study, it was revealed that the female teachers had higher mean scores obtained via the Job Description Index than the male teachers (Mahmood, Nudrat, Asdaque, Nawaz \& Haider 2011). Similarly, in one other comparative study titled "Job Satisfaction Among School Teachers' and carried out by Agnihotri (2013) in India (Nadaun Tehsil of District Hamirpur, Himachal Pradesh) with a total of 300 teachers (166 
female and 134 male) half of whom were from 46 elementary schools and the other half of whom were from 26 secondary schools, it was reported that the female teachers had higher levels of job satisfaction than the male teachers. In addition, several studies (Ayan, Kocacık \& Karakuş, 2009) carried out in Turkey with high school teachers revealed no difference with respect to gender, while there are still other studies reporting differences in favor of male teachers (Sarpkaya, 2000)

In the study, no difference was found between the job satisfaction scores of the study group teachers with respect to their school type (Table 4). However, when related studies in literature are examined, it is seen that there are studies reporting different results. For example, in studies carried out by Koruklu and colleagues (2013) and by Kuruüzüm and Çelik (2005), it was found out that school type had influence on the teachers' job satisfaction scores. In the present study, no difference was found between the study group teachers' job satisfaction scores with respect to their experience in teaching (Table 5). Similarly, Avşaroğlu, Deniz and Kahraman (2005), in their study titled "Examining Technical Teachers' Levels of Life Satisfaction, Job Satisfaction and Professional Burnout" reported that the teachers' job satisfaction scores did not significantly differ with respect to their experience in teaching. In another study titled "High School Teachers' Job Satisfaction: A Case from the City of Manisa", Sarpkaya (2000) found out that teachers' job satisfaction levels increased as their experience in teaching increased. In one other study titled "Job Satısfaction Among School Teachers", Agnihotri (2013) reported that experienced teachers had higher levels of job satisfaction in India than less experienced teachers. In the present study, it was seen that there were significant differences between the job satisfaction scores of the teachers aged between 20-30 and those aged between 41-50 with respect to the promotion opportunities in favor of the former group of teachers (Table 6). It was found out regarding the promotion opportunities that the study group teachers aged between 20-30 were more satisfied than those aged between 41-50. Similarly, in one study carried out by Ololube (2006) with 680 teachers from 146 public secondary schools in Nigeria Rivers State, it was found out that the teachers aged between 20-30 and those older than 51 had higher job satisfaction scores than those aged between 31-40 and those between 41-50. The reason why younger teachers' levels of job satisfaction demonstrated a significant difference was the fact that these teachers were just at the beginning of their professional career and that they demonstrated more optimistic behavior in terms of individual and institutional expectations.

In the study, it was revealed that the study group teachers' job satisfaction scores did not differ with respect to the location of their schools (Table 7). In one study carried out by Mahmood and colleagues (2011) with randomly-selected 785 teachers from public high schools in Pakistan, no significant difference was reported between the job satisfaction mean scores of teachers working in rural and urban areas. In the present study, considering the teaching fields of the teachers (physics, chemistry and biology), it was seen that the chemistry teachers had higher levels of job satisfaction than the biology teachers with respect to their colleagues. In the study, the teachers who were not married were more satisfied with the promotion opportunities. Depending on this finding, it could be stated that single teachers are more likely to find spare time to try to progress in their professions than married teachers. When literature is examined, it is seen that there are various related findings. In one study, Şahin (2013) reported similar results. The researcher pointed out that the single teachers participating in the study had higher job satisfaction scores with respect to general job-related issues, salary and colleagues. In another study, Canbay (2007) reported that married teachers had higher levels of job satisfaction regarding the job-related issues than single and widow teachers. On the other hand, Yilmaz and Karahan (2009), in their study, found out that marital status did not have any influence on workers' job satisfaction.

In addition, in the study, it was revealed that regarding the promotion opportunities, the job satisfaction scores of the participants with a post-graduate degree were higher than those of the participants with an undergraduate degree. Considering the fact that there will be a higher chance of promotion in case of a post-graduate degree, the result obtained in the study was not surprising. It is seen that consistent results were obtained in national and international research on teachers' job satisfaction. Institutions failing to cooperate and maintain good relations with their employees who are not satisfied with their jobs can neither prevent their employees from resigning their jobs nor develop a faithful workforce. If employees are more satisfied with their jobs, then they are less likely to quit their jobs and more likely to demonstrate organizational (expected) behavior and to be satisfied with their lives in general (Carsten \&Spector, 1987; Judge \& Watanabe, 1993). As mentioned by Oliver (2007), if a working environment is not established by administrators considering the variables influential on teachers' job satisfaction and if teachers have low levels of job satisfaction, then they will not feel themselves engaged with their schools; they will experience burnout; they will not contribute to the development of a positive organizational culture; they will not be able to go to school for teaching regularly; and there will be no increase in students' academic achievement. For all these reasons, when teachers' levels of job satisfaction increase, their engagement with the school environment will increase accordingly. In one study, Hughes (2006) reported a relationship between teachers' engagement with the organization and their belief in and acceptance of organizational objectives and stated that all these had positive influence on the teachers' performance and levels of job satisfaction. The researcher also pointed out that students' performance will increase in line with this 
positive influence. The increasing engagement of an individual with the organization will both increase the effectiveness of the organization and cause the individual to work more happily.

\section{Suggestions}

The results obtained in the study demonstrated that the participating teachers had a moderate level of job satisfaction. This moderate level of job satisfaction is likely to have negative influence on teachers' success at school, on the class atmosphere and on the learning climate. Therefore, it is necessary for teachers to achieve satisfaction in terms of internal and external motivators. For this:

Teachers could gain a better position if they work in good institutional conditions at the beginning of their professional career; if they are awarded using internal and external motivators; and if they demonstrate more optimistic behavior in terms of individual and institutional expectations.

The Ministry of National Education should rearrange its "academic structure" to allow teachers to take post-graduate education. In order for teachers to follow the scientific developments and educational activities in the world not only with academic studies but also with in-service trainings, they should be provided with financial supports. They should be encouraged to participate in national and international scientific studies.

Teachers' success should be evaluated according to objective criteria and be promoted and awarded when they deserve it.

When a teacher takes part in administrative organs at school and becomes a sharer in the decisions made, they tend to develop more positive attitudes towards their schools.

\section{References}

Akçamete, G., Kaner, S., \& Sucuoğlu, B. (2001). Tükenmişlik iş doyumu ve kişilik. Ankara, Nobel Yayınları.

Agnihotri, A. K. (2013). Job Satıffaction Among School Teachers, Indian Streams Research Journal, 3(2), 1-7.

Avşaroğlu, S., Deniz, E. M., \& Kahraman, A. (2005). Teknik Öğretmenlerde Yaşam Doyumu, İş Doyumu ve Mesleki Tükenmişlik Düzeylerinin İncelenmesi, Selçuk Üniversitesi Sosyal Bilimler Enstitüsü Dergisi, 14, 115-129. http://www.sosyalbil.selcuk.edu.tr/sos_mak/articles/2005/14/S

Ayan, S., Kocacık, F., \& Karakuş, H. (2009). Job Satisfaction Levels of High School Teachers and Affecting Personal and İnstitutional Factors: A Study of Sivas City. Anatolian Journal of Psychiatry, 10, 18-25.

Brayfield, A. H., \& Rothe, H. F. (1951). An Index of Job Satisfaction, Journal of Applied Psychology, 35, 307-311. http://dx.doi.org/10.1037/h0055617

Canbay, S. (2007). İlköğretim okullarında çalışan öğretmenlerin iş doyum ve denetim odağı ilişkisi. (Yayımlanmamış yüksek lisans tezi). Dokuz Eylül Üniversitesi, Eğitim Bilimleri Enstitüsü, İzmir.

Carsten J. M., \& Spector P. E. (1987). Unemployment, Job Satisfaction, and Employment Turnover: A Metaanalytic Test of Muchinsky Model. J. Appl. Psychol., 72, 374-381. http://dx.doi.org/10.1037/0021-9010.72.3.374

Davis, K. (1988). İşletmede İnsan Davranışı. (Translated by Kemal Tosun et.al.), Third Edition, Publication Number.199, İstanbul: İ.Ü. İşletme Fakültesi.

Delfgaauw, J. (2005). The Effect of Job Satisfaction on Job Search : Not Just Whether, But Also Where. Tinbergen Institute Discussion Paper, October, Rotterdam, Erasmus University. http://dx.doi.org/10.2139/ssrn.835425

Günbayı, İ., \& Toprak, D. (2010). A Comparison of Primary School Teachers and Special Primary School Teachers’ Job Satisfaction Levels, Elementary Education Online, 9(1), 150-169.

Eren, E. (2001). Yönetim ve Organizasyon: Çağdaş ve Küresel Yaklaşımlar. 5th Edition. Beta Yayınevi, İstanbul.

Eren, E. (2001). Örgütsel Davranış ve Yönetim Psikolojisi. İstanbul, Beta Yayınları.

Erjem, Y. (2005). Eğitimde Yabancılaşma Olgusu ve Öğretmen: Lise Öğretmenleri Üzerine Sosyolojik Bir Araştırma. Türk Eğitim Bilimleri Dergisi, 3(4), 395-417.

Ertürk, E., \& Keçecioğlu,T. (2012). Relations Between the Levels of Employees Job Satisfaction and Burnout: A Sample Application on the Teachers, Ege Academic Review, 12(1), 39-52.

Hughes, V. M. (2006). Teacher Evaluation Practices and Teacher Job Satisfaction, Unpublished Dissertation. University of Missouri, Columbia.

Judge, N. A., \& Watanabe, S. (1993). Another Lock at the Satisfaction-Life Satisfaction Relationship. J. Appl. Psychol., 78, 939-948. http://dx.doi.org/10.1037/0021-9010.78.6.939 
Judge, T. A., Parker, S., Colbert, A. E., Heller, D., \& Ilies, R. (2001). Job satisfaction: A Cross-Cultural Review. In N. Andersen, D. S. Ones, H. K. Sinangil, \& C. Viewesvaran (Eds.), Handbook of industrial, work and organizational psychology, 2, Organizational psychology (pp. 25-52). London: Sage.

Kuruüzüm, A., \&, Çelik, N. (2005). Anal Yzıng The Factors That Determıne Teacher Job Satısfactıon By Second Order Factor Model. Hacettepe Üniversitesi Eğitim Fakültesi Der isi (H. U. Journal of Education) 29, 137-146.

Mahmood, A., Nudrat, S., Asdaque, M. M., Nawaz, A., \& Haider, N. (2011). Job Satisfaction of Secondary School Teachers: A Comparative Analysis of Gender, Urban and Rural Schools, Asian Social Science, 7(8), 203-208.

Maslow, A. (1970). Motivation and Personality, Harper \& Row Publishers, Second edition, USA

Newstrom, J. W. (1986). Human behavior at work. New York. McGraw-Hill.

Oliver, R. E. (2007). Relationship Between Teacher Job Satisfaction and Teaming Structure at the Middle School Level. Unpublished dissertation, University of Kansas, Kansas.

Ololube, N., P. (2006). Teachers Job Satisfaction and Motivation for School Effectiveness: An Assessment, Essays in Education (EIE), 18, 1-19.

Bozkurt, Ö., \& Bozkurt, İ. (2008). İş Tatminini Etkileyen İşletme İçi Faktörlerin Eğitim Sektörü Açısından Değerlendirilmesine Yönelik Bir Alan Araştırması, Doğuş Üniversitesi Dergisi, 9(1), 1-1.

Rinehart, J. S., \& Short, P. (2003). Job Satisfaction and Empowerment Among Teacher Leaders, Reading Recovery Teachers and Regular Classroom Teachers. Education, 114(4), 570-580.

Sarpkaya, R. (2000). Lisede Çalışan Öğretmenlerin İş Doyumu: Manisa İli Örneği. Amme İdaresi Dergisi, 33(3), 111-124.

Smith, P. C., Kendall, L. M., \& Hulin, C. L. (1969). Measurement of Satisfaction in Work and Retirement. Chicago, IL: Rand McNally.

Stempien, L. R., \& Loeb, R. C. (2002). Differences in Job Satisfaction Between General Education and Special Education Teachers: Implication For Retention. Remedial and Special Education, 23(5), 258-268. http://dx.doi.org/10.1177/07419325020230050101

Şahin, İ. (2013). Öğretmenlerin İş Doyumu Düzeyleri YYÜ Eğitim Fakültesi Dergisi (YYU Journal Of Education Faculty), Cilt:X, Say1:I, 142-167, http://efdergi.yyu.edu.tr

Şimşek, L. (1995). İş tatmini. Verimlilik Dergisi, Milli Prodüktivite Merkezi, 2, 91-102.

Tasnim, S. (2006). Job Satisfaction among Female Teachers: A Study on Primary Schools in Bangladesh. https//bora.uib.no/handle/1956/1474,2006. Access Date: 23.04.2013.

Türk, E. D. (2009). Öğretmen Yeterlikleri. http://portal.ted.org.tr/yayinlar/Ogretmen_Yeterlik_Kitap.pdf, Access Date: 24.04.2013

Williams, K., \& Poel, E. W. (2006). Stress Management for Special Educators: the Self Administered Tool for Awareness and Relaxtion (Star), Teaching Exceptional Children Plus, 3(1), 1-12.

\section{$(\mathrm{oc}) \mathrm{BY}$}

This work is licensed under a Creative Commons Attribution 3.0 License. 